\title{
SPONSORSHIP MARKETING UNTUK MEMPERTAHANKAN CITRA MEREK PADA ERA DIGITAL: STUDI KASUS SPECIAL EVENT HARIAN KOMPAS
}

\author{
Tarrence Karmelia Kontessa \\ Prodi Ilmu Komunikasi, Jurusan Komunikasi Strategis, Universitas Multimedia Nusantara \\ Korespondensi: Jalan Boulevard Gading Serpong, Tangerang \\ Surel: tarrence.karmelia@lecturer.umn.ac.id
}

INFO ARTIKEL

Sejarah Artikel:

Diterima: $27 / 03 / 20$

Direvisi: 13/05/20

Dipublikasikan:

$31 / 05 / 20$

e-ISSN: 2721-0995

p-ISSN: 2721-9046

Kata Kunci:

Sponsorship Marketing, Citra Merek, Special Event, Event Management

Keywords:

Marketing Sponsorship, Brand Image, Special

Events, Event Management
ABSTRAK

Sponsorship Marketing untuk Memertahankan Citra Merek pada Era Digital: Studi Kasus Special Event Harian Kompas. Menghadapi era digital, media cetak semakin menghadapi risiko disrupsi akibat gerusan perubahan zaman yang kian paperless. Penelitian ini membatasi diri pada pertanyaan bagaimana Harian Kompas sebagai sebuah media mengelola berbagai special event-nya dengan memanfaatkan kekuatan dan sumber daya media cetak terbesar di Indonesia. Selain itu, penelitian ini juga membahas bagaiamana merancang sebuah event management yang baik untuk memperkuat citra merek perusahaan. Metode yang digunakan dalam penelitian ini adalah studi kasus dengan pendekatan kualitatif deskriptif. Teknik pengumpulan data dilakukan dengan wawancara, observasi, dan studi kepustakaan. Analisi data diuji dengan teknik triangulasi. Hasil penelitian menunjukkan Harian Kompas berhasil mengelola sebuah event management yang terbukti mampu memperkuat brand image Harian Kompas. Bahkan, menjadikan special event sebagai revenue stream baru bagi harian ini.

\section{ABSTRACT}

Sponsorship Marketing to Maintain Brand Image in Digital Age: Case Study of Kompas Daily's Special Events. Facing the digital era, print media face an increasing risk of disruption due to the paperless trend. Kompas Daily made various efforts to maintain its brand image like organizing some special events. This research limits itself to the question of how Kompas Daily manages its various special events, by utilizing its strengths and resources as the largest Indonesia's print media, and by designing a good event management to strengthen the company's brand image. The method used is a case study with a descriptive qualitative approach. Data are collected through interviews, observation and literature study and then tested by triangulation techniques. The results showed Kompas Daily succeeded in develop an event management proven to be able to strengthen Kompas Daily's brand image, and even succeeded in making the special events as a new revenue stream. 


\section{PENDAHULUAN}

Persaingan ketat pada era digital sekarang ini mendorong sebuah produk untuk terus berinovasi menyesuaikan diri dengan zaman dan teknologi yang terus berkembang. Bagi media cetak, situasi ini dipersulit dengan perubahaan kebiasaan yang terjadi di masyarakat dalam mengonsumsi media. Media cetak mulai kesulitan bertahan di tengah masyarakat, karena bersaing dengan media digital. Di tengah situasi sulit ini, Harian Kompas merasa perlu melakukan inovasi untuk terus membentuk citra merek yang positif agar dapat memertahankan kepercayaan pelanggan. Strategi komunikasi untuk meningkatkan citra merek (brand image) kemudian menjadi penting karena disadari, keputusan konsumen tentang produk apa yang akan mereka beli berkaitan sangat erat dengan persepsi konsumen terhadap produk.

Untuk mempertahankan citra merek Kompas dari ancaman gerusan perubahan zaman, Kompas memanfaatkan salah satu perangkat public relations, yaitu special events. Dalam konteks Marketing Public Relation, salah satu strategi yang sering digunakan untuk mengomunikasikan merek adalah sponsorship marketing. Yang salah satunya ialah penyelenggaraan event. Special events didefinisikan oleh Mac Namara sebagai sebuah acara yang dilakukan untuk menarik perhatian media terhadap klien, perusahaan, ataupun produk. Acara tersebut juga dapat menjadi sebuah media untuk menyampaikan pesan secara spesifik mengenai produk perusahaan.

Special events Harian Kompas terbagi atas empat segmen khusus, yaitu: Event Scholastic (Kompas 100 CEO Forum), Event Sport Tourism (Borobudur Marathon, Jakarta Kizuna Ekiden, Kompas Tambora Challenge, Liga Kompas Gramedia U-14, Jelajah Sepeda, Semarang 10K), Event Expo (Kompas Travel Fair, Festival Foto Kompas, Festival Kopi), dan Event Komunitas. Melalui keempat segmentasi ini, event Harian Kompas berusaha memperkuat citra merek Harian Kompas sebagai media yang tepercaya, penyambung lidah rakyat, amanat hati nurani rakyat. Hingga saat ini, tiga segmentasi sudah berjalan dengan baik. Namun, satu segmen, yakni Event Komunitas masih dalam tahap persiapan untuk diluncurkan.

Secara khusus juga disebutkan, event Harian Kompas bertujuan untuk memaksimalkan potensi dan kekayaan yang dimiliki Indonesia. Karena tak dapat dipungkiri, Indonesia memiliki keindahan alam, ragam seni budaya, serta populasi yang begitu melimpah, sehingga penyelenggaraan event yang bernilai luhur dan diadakan sepanjang tahun diyakini dapat menjadi cara untuk memaksimalkan berbagai potensi dan kekayaan itu. Selain itu, ada tugas mulia dibalik penyelenggaraan event Harian Kompas, yakni memberikan dampak dan kontribusi bagi Indonesia, seperti menarik banyak investor untuk berinvestasi hingga memberdayakan usaha lokal. Ini semua untuk meningkatkan perekonomian warga dan pariwisata daerah. 


\section{TINJAUAN PUSTAKA}

\section{Marketing Public Relations}

Harris (Ruslan, 2014: 245) menjabarkan definisi Marketing Public Relations sebagai sebuah perencanaan dan evaluasi program dalam merangsang penjualan dan pelanggan melalui komunikasi tentang informasi yang kredibel dan kesan yang menggambarkan perusahaan dengan produk dan perhatian pelanggan. Menurut Kotler (Ruslan, 2014: 246), "Marketing Public Relations works because it adds value to product through it's unique ability to lend credibility to product message." Marketing Public Relation bekerja karena dapat memberikan nilai melalui kemampuannya yang unik dalam menunjukkan kredibilitas produk. Dengan kata lain, Marketing Public Relations merupakan perpaduan antara fungsi public relations yang digunakan untuk mendorong penjualan dan membentuk kepuasan konsumen.

\section{Sponsorship Marketing}

Sponsorship marketing memiliki dua elemen, yaitu event dan cause sponsorships yang berfungsi untuk mencapai tujuan perusahaan terutama dalam meningkatkan citra perusahaan dan tingkat penjualan. Sponsorship meliputi dua aktivitas utama, yaitu pertukaran antarsponsor seperti merek tertentu dengan yang disponsori misalnya event olahraga. Dalam hal ini yang disponsori menerima dana dan pemberi sponsor mendapat hak untuk terlibat dalam kegiatan yang disponsori dan pemasaran asosiasi oleh sponsor.

Dalam pertumbuhan sponsorship ada lima faktor yang berpengaruh, yaitu:

1. Dengan terlibat dalam sebuah event dan causes, perusahaan kemungkinan dapat menghindari kekusutan dalam periklanan.

2. Sponsorship membantu perusahaan dalam merespon perubahan kebiasaan media konsumen.

3. Sponsorship dapat membantu perusahaan untuk mendapat persetujuan dari beberapa pihak termasuk stakeholders, karyawan, dan masyarakat luas.

4. Hubungan antara merek dengan acara yang disponsori dapat meningkatkan brand equity dengan meningkatkan awareness konsumen dan meningkatkan citra perusahaan.

5. Sponsorship dapat memungkinkan perusahaan untuk menargetkan sasaran komunikasi mereka kepada kelompok yang lebih spesifik baik secara lokasi maupun gaya hidup (Andrews \& Shimp, 2013: 491).

\section{Special Events}

Special events didefinisikan oleh Mac Namara (Ruslan, 2014: 232-233) sebagai sebuah acara yang dilakukan untuk menarik perhatian media baik terhadap klien perusahaan maupun produk. Acara tersebut juga dapat menjadi sebuah media untuk menyampaikan pesan secara spesifik mengenai produk perusahaan. Selain itu, special events sendiri juga dapat berupa peluncuran atau publisitas produk.

Special event memiliki beberapa bentuk menurut Ruslan (2014: 235-236), yaitu 
Festival, Fair, Parade, Seminar, dan Open House. Sementara itu, menurut jenisnya dalam kegiatan public relation, special event secara umum memiliki tiga jenis, di antaranya ialah (1) acara peresmian, (2) peringatan tertentu, dan (3) acara komersial (peluncuran produk baru) atau nonkomersial.

Tujuan special event menurut Ardianto (2004: 103) berkaitan dengan kepentingan tertentu, misalnya pengenalan awareness dan meningkatkan pengetahuan tentang perusahaan atau produk, proses publikasi yang memperoleh publisitas positif, memperlihatkan itikad baik sekaligus memberikan citra positif terhadap masyarakat sebagai sasarannya, mempertahankan penerimaan masyarakat, dan memperoleh rekanan atau pelanggan baru.

\section{Event Management dan Brand Image}

Glenn McCartney (2010:148) menyatakan ada beberapa hal dalam penyusunan konsep event, yaitu Generating of Event Ideas, Objective Setting, Screening Process, Feasibility Testing, Concept Refining, Implementation and Monitoring, Review and Evaluation. Sementara itu, Keller mendefinisikan brand image sebagai persepsi konsumen tentang sebuah merek, seperti tercermin dalam asosiasi merek dalam ingatan konsumen (2013: 72). Brand image yang positif juga menjadi pengaruh dalam memori konsumen mengenai brand dan memengaruhi persepsi konsumen tentang brand tersebut.

Menurut Wiryawan (2008:32) citra merek merupakan cara konsumen membayangkan atau memercayai sebuah merek. Menurut Keller dalam bukunya yang berjudul Strategic Brand Management, menyebutkan bahwa membangun citra positif membawa ikatan yang kuat, menguntungkan, dan berkesan unik dalam memori.

\section{METODE}

Jenis penelitian yang digunakan oleh penulis adalah deskriptif kualitatif. Dalam penelitian ini, penulis tidak menguji hipotesis tertentu, tetapi menjelaskan fenomena, gejala, atau keadaan melalui data-data yang diperoleh. Pendekatan kualitatif pada penelitian ini dimanfaatkan untuk membahas secara lebih rinci mengenai suatu fenomena yang kemudian dirincikan secara deskriptif. Metode penelitian yang digunakan penulis adalah studi kasus. Menurut Yin (2018:18), studi kasus merupakan suatu inkuiri empiris yang menyelidiki fenomena di dalam konteks kehidupan nyata, bilamana batas-batas antara fenomena dan konteks tidak tampak secara tegas atau jelas dan memanfaatkan berbagai sumber bukti. Ada tiga tipe studi kasus menurut Yin (2013: 1), yaitu eksplanatoris, eksploratoris, dan deskriptif.

Studi kasus dipilih untuk memberikan kesempatan kepada peneliti memahami secara mendalam aspek-aspek dasar strategi event management Harian Kompas dalam upaya mempertahankan citra merek Harian Kompas. Uji keabsahan data dilakukan lewat triangulasi sumber, yaitu melakukan verifikasi dengan tiga perbandingan, yaitu kerangka teori, studi dokumen, dan hasil wawancara (Kriyantono, 2010: 72). Apabila ketiga hal ini sama, maka penelitian tersebut benar adanya dan memiliki kredibilitas. Triangulasi yang 
digunakan adalah triangulasi dengan sumber, yaitu membandingkan data hasil observasi, studi dokumen, dan hasil wawancara terhadap subjek. Dalam penelitian ini penulis menggunakan teknik triangulasi sumber karena dapat diklarifikasikan maknanya dengan cara mencari kesamaan di antara narasumber.

\section{HASIL DAN PEMBAHASAN}

Harian Kompas menyadari bahwa media konvensional saat ini mengalami gerusan yang cukup dahsyat karena adanya kemajuan teknologi yang pesat. Oleh karena itu, perusahaan perlu melakukan langkah inovasi untuk mempertahankan bisnisnya. Salah satu inovasi yang dilakukan adalah melalui penyelenggaraan event Harian Kompas. Terdapat dua fungsi utama dari event Harian Kompas. Pertama adalah untuk memperkuat citra merek Harian Kompas dalam menghadapi era digital yang berisiko disrupsi digital seperti juga dihadapi oleh seluruh media konvensional di dunia. Kedua adalah sebagai medium baru untuk pemasang iklan. Event Harian Kompas, harus bisa menjadi alternatif bagi pemasang iklan untuk beriklan.

Citra merek Harian Kompas memegang peranan sangat penting dalam situasi disrupsi digital ini karena para pelanggan Harian Kompas menjadi tidak terlalu merasakan dahsyatnya terpaan situasi yang sedang dihadapi ini. Harian Kompas merasa pemanfaatan event sebagai salah satu cara untuk mengatasi masalah yang ditimbulkan disrupsi digital adalah sebuah strategi yang bagus. Diharapkan, dengan lima sampai sepuluh event besar saja, permasalahan gerusan era digital yang dihadapi akan dapat teratasi. Saat ini, dari sekian banyak event Harian Kompas, sudah ada beberapa event yang mendapatkan predikat memuaskan. Kompas Travel Fair sudah menjadi event travel fair terbesar, Borobudur Marathon sudah menjadi event lari terbaik, dan Tambora Challenge menjadi event ultra marathon terfavorit di Indonesia. Diharapkan, event lain segera menyusul.

Event Harian Kompas dirancang sebagai eventyang berkelanjutan. Ibarat membangun sebuah sumur, suatu saat akan menjadi sumber mata air. Di masa awal mungkin event Harian Kompas belum menghasilkan secara signifikan, tapi bila dipertahankan secara terusmenerus, suatu saat akan menjadi sumber revenue baru bagi perusahaan. Beberapa event yang saat ini belum terlihat menguntungkan secara signifikan, seperti Tambora Challenge, tetap dipandang sebagai potensi yang akan menjadi besar pada kemudian hari. Omset besar sekitar 50 sampai 100 miliar rupiah per event per tahun, memang menjadi target bagi Divisi Event Harian Kompas, karena divisi ini memang diharapkan dapat menolong Harian Kompas dalam menghadapi penurunan pemasukan akibat disrupsi digital.

Banyak hal yang telah dilakukan Harian Kompas dalam menerapkan metodemetode untuk menghasilkan keuntungan dari event-event yang dikelolanya, antara lain melalui kerjasama dengan pihak sponsor, penjualan tiket, broadcasting televisi dan radio, iklan dalam halaman khusus di Harian Kompas, dan penjualan merchandise. Kerjasama dengan pihak sponsor selama ini berjalan baik dan event Harian Kompas mendapat masukan yang baik dari para sponsor. Dalam event Borobudur Marathon misalnya, Dirut Bank Jateng 
yang menjadi sponsor utama sangat berterima kasih dapat terlibat dalam event ini karena ternyata mampu menaikkan omset bank itu menjelang Initial Public Offering (IPO) dari saham mereka.

Sementara CIMB sebagai sponsor KTF (Kompas Travel Fair Jakarta) 2019, merasa puas karena target peningkatan pencapaian omset mereka tercapai. Termasuk sponsor KTF Daerah dari BNI juga puas, dan berpeluang untuk diajak menjadi partner yg lebih besar, misalnya untuk Jakarta. Dari sisi broadcasting, saat ini sudah bermunculan tawaran dari beberapa media televisi dan radio untuk membeli hak siar event-event Harian Kompas. Pada masa depan, Harian Kompas menargetkan broadcasting event menjadi salah satu sumber pemasukan event Harian Kompas. Sementara penjualan tiket, iklan dalam halaman khusus Kompas dan Merchandise juga adalah pos-pos yang terus dikembangkan dari waktu ke waktu.

Ada dua hal yang menjadi kekhasan special event Harian Kompas. Pertama adalah dari sisi besarannya. Harian Kompas menginginkan event yang dikelolanya menjadi yang terbesar, terbaik, berdampak dan memiliki efek "wow". Artinya, special event Kompas sejak semula memang ditargetkan untuk menjadi event unggulan dalam bidangnya. Kedua adalah dari sisi dampaknya. Event Harian Kompas harus berdampak positif terhadap masyarakat, antara lain mampu mengangkat perekonomian masyarakat di lokasi berlangsungnya event. Hal seperti ini sudah terjadi dalam event Borobudur Marathon, Kompas Travel Fair, dan Kompas Tambora Challenge.

Bahkan, event Borobudur Marathon terbukti mampu menciptakan destinasi wisata baru bagi para turis baik lokal maupun mancanegara. Begitu pula event Semarang $10 \mathrm{~K}$, yang mulai menjadi destinasi heritage bagi penikmat sejarah dan juga menjadi target Harian Kompas bersama pemerintah daerah setempat untuk mengembangkan usaha kecil dan menengah di masyarakat. Harian Kompas memosisikan dirinya bukan sebagai event organizer, tapi lebih sebagai konsultan komunikasi. Jadi yang ditawarkan kepada para klien bukan hanya jasa penyelenggaraan event, tetapi strategi komunikasi. Jadi semacam konsultan komunikasi melalui event. Banyak potensi event yang bisa digarap oleh Harian Kompas. Namun, Harian Kompas masih memiliki kendala terkait kebutuhan Sumber Daya Manusia.

Harian Kompas memandang event sebagai sebuah picu untuk mengomunikasikan pesan. Oleh karena itu, Tim Event Harian Kompas perlu memikirkan cara mengomunikasikan pesan itu melalui kanal-kanal yang ada. Hal ini juga terkait dengan keberadaan Harian Kompas sebagai media. Kegiatan special event Harian Kompas sering disebut sebagai "turunan content", misalnya Borobudur Marathon merupakan turunan atau kelanjutan dari liputan Redaksi Harian Kompas sebelumnya. Sementara, event Kompas Travel Fair adalah kelanjutan dari kegiatan sebelumnya dari bagian iklan Kompas.

Event Harian Kompas, tentu membutuhkan dukungan dari Redaksi Harian Kompas terutama dalam konteks ruang publikasi. Meski demikian, tentu saja Redaksi Harian Kompas tidak mau ruang berita dicampuri oleh urusan bisnis sehingga menjadi tugas Divisi Event 
Harian Kompas juga untuk membuat event yang memiliki bobot pemberitaan yang baik. Di samping itu, Divisi Event Harian Kompas perlu menjalin komunikasi yang baik dengan pihak redaksi, agar informasi-informasi seputar special event yang diselenggarakan bisa disampaikan kepada mereka secara lancar.

Secara omset, kegiatan special event Harian Kompas telah mendatangkan banyak pemasukan kepada Harian Kompas. Pemasukan ini terus naik dan berkembang dari tahun ke tahun. Dibandingkan empat tahun lalu, ketika Divisi Event didirikan untuk semakin memfokuskan kegiatan special event Harian Kompas, omsetnya telah naik berkali lipat. Hal ini membuat event dipandang sebagai peluang yang menjanjikan bagi Harian Kompas. Bahkan, pendapatan dari special event Harian Kompas ini diyakini akan bisa menyaingi pendapatan iklan Harian Kompas.

Event Harian Kompas juga sudah masuk dalam radar media internasional. Misalnya event Borobudur Marathon dan event Tambora Challenge. Bagi Harian Kompas tentu ini juga merupakan sebuah pengakuan. Intinya event Kompas dianggap baik dan pelaksanaannya memberi dampak besar, mendapat berbagai pencapaian, yang semuanya itu otomatis berdampak langsung pada upaya mempertahankan citra merek Kompas. Sebagai event yang diselenggarakan oleh perusahaan media, tim bisnis Harian Kompas diharapkan dapat berkontribusi besar dalam mempertahankan citra merek Kompas, yang akhirnya berdampak pula pada citra merek Harian Kompas sebagai media cetak terbesar dan berpengaruh di Indonesia. Banyak penawaran yang datang pada Divisi Event Harian Kompas untuk kerjasama penyelenggaraan event. Namun, tidak sedikit pula yang akhirnya terpaksa ditolak.

Harian Kompas harus berhati-hati dengan kemungkinan event tidak berjalan dengan baik karena tidak adanya sumber daya manusia yang tepat dan cukup kompeten untuk menangani suatu event. Ibarat pesanan makanan, jangan sampai Harian Kompas tidak memiliki chef yang tepat untuk membuat makanan tersebut. Prinsip kehati-hatian ini dijaga betul oleh Harian Kompas, meskipun ada tuntutan untuk mengejar target omset tertentu karena bila salah penanganan, sebuah event malah dapat berdampak buruk terhadap citra merek. Bukannya memperkuat, tapi malah melemahkannya.

Penerapan public relation dalam Kompas menjadi salah satu upaya yang dilakukan oleh Kompas untuk mengimplementasikan proses komunikasi yang terarah. Pada dasarnya public relation memiliki peranan strategis dalam pencapaian tujuan perusahaan dan menjadi jembatan untuk membangun komunikasi serta persepsi yang sama antara perusahaan dengan publiknya. Selain itu, public relation juga menjadi penghubung untuk menyamakan persepsi antara perusahaan dengan audiensnya. Kompas yang sebenarnya sudah lama ada dalam dunia media konvensional melakukan penerapan strategi public relation, yaitu special events yang merupakan salah satu tool dari public relation.

Kompas menggunakan strategi komunikasi public relation untuk meningkatkan citra merek perusahaan dengan menyelenggarakan berbagai event yang kemudian memberikan dampak positif bagi masyarakat, sehingga menimbulkan persepsi positif baik dari masyarakat maupun audience. Hasil yang diharapkan adalah memperkuat citra merek 
perusahaan, kemudian meningkatkan kepercayaan dari masyarakat.Upaya marketing public relations adalah menggabungkan startegi public relation dengan konsep marketing. Kompas menerapkan konsep sponsorship marketing sebagai salah satu strategi untuk melalukan promosi dan mengomunikasikan tujuan serta pesan dari perusahaan.

Sponsorship marketing sendiri merupakan sebuah konsep dengan dua elemen penting, yaitu event dan cause sponsorships untuk meningkatkan citra perusahaan dan penjualan. Sponsorship marketing juga memiliki dua aktivitas utama yaitu kedua belah pihak, baik sponsor maupun yang disponsori mendapatkan haknya masing-masing dan asosiasi mendapat pemasaran dari kedua belah pihak. Sponsorship marketing dalam event Harian Kompas membawa pengaruh yang signifikan bagi Harian Kompas karena membawa nama besar Kompas sebagai penyelenggara, bekerja sama dengan pihak sponsor. Sponsorship memang menjadi andalan bagi event Harian Kompas selama ini dalam mendapatkan revenue. Namun, prinsip kehati-hatian tetap menjadi panduan utama. Perlu ada kesamaan visi dan misi antara pihak sponsor dengan Harian Kompas.

Jika suatu kerja sama sponsorship sudah diupayakan sedemikian rupa agar sesuai dengan visi dan misi Harian Kompas tetapi tidak juga menemukan titik terang, maka biasanya Harian Kompas memilih untuk membatalkannya, dan menyerahkan peluang itu kepada anggota grup perusahaan Kompas Gramedia yang lain. Dalam pelaksanaan event, tentu membutuhkan persiapan dan penyusunan konsep yang terstruktur agar menghasilkan sebuah event yang maksimal. Keputusan perusahaan dalam menjadikan event sebagai sarana untuk membangun, mengelola, dan meningkatkan citra merek perusahaan tentu merupakan keputusan yang memiliki nilai dan tujuan besar. Oleh karena itu, perusahaan tentunya melakukan persiapan secara maksimal.

Harian Kompas pada event Borobudur Marathon 2018 misalnya, melakukan persiapan dan perencanaan yang matang untuk mendukung keberlangsungan acara, terutama mengingat Harian Kompas bukan merupakan penyelenggara pertama dalam acara Borobudur Marathon 2018 ini setelah sebelumnya dilaksanakan pada 2017. Melalui riset, Harian Kompas melihat tren lomba lari maraton sedang berkembang di tengah masyarakat. Event marathon sendiri di Indonesia sebenarnya sudah banyak terlaksana di berbagai daerah, termasuk di kota-kota besar seperti Jakarta dan Bali. Kompas melihat kesempatan ini sebagai peluang untuk menyelenggarakan sebuah event yang unik dan berbeda.

Riset dilakukan tidak hanya menghasilkan gambaran tren di tengah masyarakat, tetapi juga apa yang diperlukan masyarakat serta apa yang dapat menjadi nilai plus bagi event yang akan diselenggarakan oleh Harian Kompas. Nilai pariwisata di daerah Magelang menjadi salah satu hasil riset dan menjadi pertimbangan Harian Kompas dalam melaksanakan event. Selain melakukan riset terhadap kondisi tren serta apa yang dibutuhkan oleh masyarakat, Kompas juga melakukan analisis terhadap kompetitor, yakni penyelenggara event marathon lainnya yang sudah pernah dilakukan oleh perusahaan lainnya. Di sini Kompas melihat celah-celah untuk melaksanakan sesuatu yang berbeda dari kompetitornya sehingga ini yang membedakan antara event Borobudur Marathon 2018 dengan event yang lain. 
Kompas melihat ada banyak faktor yang dapat diangkat sebagai keunikan Borobudur Marathon, di antaranya ada keunikan lokasi Borobudur Marathon yang merupakan lomba lari maraton yang dikelilingi oleh keindahan lingkungan di Magelang sehingga peserta dapat juga melihat keindahan kota Magelang. Dari sisi objective setting, Borobudur Marathon ini bertujuan menciptakan persepsi positif dari masyarakat mengenai Harian Kompas bukan hanya sebagai media yang berpengaruh dalam pemberitaan, tetapi juga merupakan media yang memberi pengaruh bagi kesejahteraan masyarakat. Kemudian tujuan sekundernya adalah meningkatkan value perusahaan yang bukan hanya sebagai perusahaan media konvensional tetapi juga sebagai konsultan komunikasi melalui event.

Kemudian screening process, poin ketiga yang perlu dilakukan dalam proses penyusunan konsep event. Screening process dalam kasus event Borobudur Marathon 2018 dilakukan dengan meninjau ulang lokasi yang akan dilalui oleh peserta sehingga lebih efektif dan dapat mencapai salah satu tujuan dari Borobudur Marathon, yaitu memamerkan keindahan lingkungan. Pemilihan jalur yang dilalui oleh peserta juga melalui proses ini sehingga menjadi daya tarik bagi target audiensnya. Pada poin selanjutnya ada feasibility testing. Pimpinan Harian Kompas dianggap sebagai stakeholder yang memiliki peranan penting dalam setiap keputusan yang dibuat oleh tim. Oleh karena itu, pengujian konsep dari event ini kemudian diujicobakan untuk melihat respon dari stakeholders.

Lalu concept refining, yaitu penyempurnaan konsep Harian Kompas dalam mengimplementasikan apa yang telah tersusun di tahap sebelumnya, untuk dilakukan penyesuaian baik dari produksi, desain, maupun cara untuk memasarkan event Borobudur Marathon. Pada tahapini Harian Kompasjuga melakukan koordinasiuntukmengomunikasikan strategi yang disebut "365 Days to Marathon". Dalam strategi itu yang termasuk empat hal penting ialah attract, engage, convert dan retain. Terakhir dibentuklah tim yang terdiri dari tim produksi, tim acara, dan tim komunikasi untuk kelangsungan acara dengan tujuan untuk mencapai ekspektasi pada event. Di sini Harian Kompas melakukan pembentukkan tim yang bertanggung jawab atas bagiannya masing masing sehingga fokusnya tidak terpecah dan setiap bagian yang ada melaksanakan tugasnya secara maksimal.

Selanjutnya tahap implementation and monitoring, yakni Harian Kompas mengimplementasikan strategi yang telah disusun pada tahap sebelumnya. Harian Kompas menggandeng cukup banyak media ataupun tools untuk melakukan promosi event, baik melalui media milik grup media Kompas maupun media partner. Selain itu, Harian Kompas juga memanfaatkan media sosial sebagai alat promosi karena melihat traffic penggunaan media sosial yang cukup tinggi dan pengaruhnya yang besar. Terakhir ada review and evaluate, dalam pelaksanaan event yang telah melalui proses perencanaan kemudian diimplementasikan pada tahapan terakhir setelah acara dilakukan evaluasi untuk melihat kekurangan guna diperbaiki pada event berikutnya. Pada kasus Borobudur Marathon 2018, Harian Kompas melihat ada sedikit kesulitan pada permasalahan registrasi sehingga di event berikutnya diperbaiki sistem registrasinya.

Feed back positif dari masyarakat kemudian dirasakan oleh Kompas dengan 
keberhasilan acaranya. Masyarakat merasakan dampak positif dari acara yang diadakan sehingga Kompas mendapat dukungan dari masyarakat untuk melaksanakan event berikutnya di daerah Magelang. Keberhasilan sebuah event Harian Kompas sangat memengaruhi citra mereknya sebagai perusahaan yang berpengaruh secara positif, seperti yang dinyatakan oleh Keller (2013:72) bahwa brand image merupakan persepsi konsumen mengenai sebuah brand, seperti tercermin dalam asosiasi brand pada ingatan konsumen.

\section{SIMPULAN}

Melalui penelitian ini dapat disimpulkan bahwa Harian Kompas berhasil menerapkan strategi sponsorship marketing melalui penyelenggaraan special event. Keberhasilan ini kemudian membawa pengaruh positif, baik bagi audience maupun masyarakat di sekitarnya, serta secara otomatis meningkatkan citra merek Harian Kompas. Pengelolaan yang baik juga menjadikan special event Harian Kompas menjadi revenue stream yang baru sehingga dapat disimpulkan bahwa penyelenggaraan event dapat menjadi opsi yang baik bagi perusahaan media cetak untuk bertahan dalam situasi disrupsi media cetak di era digital ini. Penelitian kualitatif ini mendasarkan diri pada konsep event yang dicetuskan oleh Glenn McCartney. Dibutuhkan penelitian selanjutnya baik secara kualitatif maupun kuantitatif, yang menggunakan konsep event dari pakar-pakar komunikasi lainnya untuk kemudian dibandingkan hasilnya.

\section{DAFTAR RUJUKAN}

A. Shimp, Terence. and J. Craig, Andrews. (2013). Advertising, Promotion, and Other Aspects of Integrated Marketing Communications. Boston: Cengage Learning. Ardianto, Elvinaro. (2011). Metodologi Penelitian untuk Public Relations Kuantitatif dan Kualitatif. Bandung: Simbiosa Rekatama Media.

Ardianto, Elvinaro. (2011). Handbook of Public Relations: Pengantar Komprehensif.

Bandung: Simbiosa Rekatama Media.

Astuti, Prida Ariani Ambar. (2011). Membangun Merek Melalui Penyelenggaraan Sebuah

Event: Studi Kasus Pada Event "Sour Sally Just Wanna Have Fun", Jurnal Aspikom, 1(2), 183-196.

Broom, Glen M. \& Sha, Bey Ling. (2013). Cutlip and Center's Effective Public Relations

11th ed. England: Pearson Education.

Dantes, Nyoman.(2012). Metode Penelitian. Yogyakarta: Andi Offset.

Davis, Anthony. (2007). Mastering Public Relations 2nd ed. New York: Palgrave

Macmillan.

Kartajaya, Hermawan. (2010). Brand Operation. Jakarta: Esensi.

Keller, Kevin Lane. (2008). Strategic Brand Management: Building, Measuring, and

Managing Brand Equity Third Edition. New Jersey: Pearson Education, Inc.

Kompas Korporasi (n.d). Event Harian Kompas. Retrieved from

https://korporasi.kompas.id/produk/event/ 
Kriyantono, Rachmat. (2010). Teknik Praktis Riset Komunikasi: Disertai Contoh

Praktis Riset Media, Public Relations, Advertising, Komunikasi Organisasi,

Komunikasi Pemasaran. Jakarta: Kencana Prenada Media.

Nurjaman, Kadar \& Khaerul Umam. (2012). Komunikasi \& Public Relations: Panduan untuk Mahasiswa, Birokrat, dan Praktisi Bisnis. Bandung: CV Pustaka Setia.

Noor, Any. (2013). Manajemen Event Edisi Revisi. Bandung: Penerbit Alfabeta.

Salam, Muslim. (2011). Metodologi Penelitian Sosial: Kualitatif Menggugat Doktrin

Kuantitatif. Makassar: Masagena Press.

Salim, Agus.(2006). Teori dan Paradigma Penelitian Sosial. Yogyakarta: Tiara Wacana.

Seitel, F. P. (2011). The Practice of Public Relations $11^{\text {th }}$ ed. New Jersey: Pearson.

Sugiyono. (2009). Metode Penelitian Kuantitatif Kualitatif dan R\&D. Bandung: Alfabeta.

Suharsaputra, Uhar. (2012). Metode Penelitian Kuantitatif, Kualitatif, dan Tindakan.

Bandung: PT Refika Aditama.

Sugiyono. (2005). Memahami Penelitian Kualitatif. Bandung: Alfa Beta.

Wiryawan, B. Mendiola. (2008). Kamus Brand A-Z. Jakarta: Red \& White Publishing.

Wulandari, Deasy dkk. (2015). Event Marketing sebagai Strategi Meningkatkan

Brand Awareness, Bisma: Jurnal Bisnis dan Manajemen, 9(1), 43-55.

Yeorish, Jacqueline. (2019). Strategi Event Borobudur Marathon 2018 dalam Meningkatkan

Brand Image Harian Kompas. Skripsi tidak dipublikasikan. Universitas Multimedia Nusantara 